\title{
ENZYMATIC TREATMENT OF WOOL FABRICS WITH LIPASE IN THE IMPROVEMENT OF SOME PROPERTIES OF WOOL FABRICS
}

\author{
Kiro Mojsov ${ }^{1 *}$, Aco Janevski' , Darko Andronikov', Sonja Jordeva', \\ Stevan Gaber' ${ }^{2}$ Ivan Ignjatov ${ }^{2}$
}

\footnotetext{
1 University "Goce Delchev", Faculty of Technology, Shtip, Republic of North Macedonia

*e-mail: kiro.mojsov@ugd.edu.mk

2University "Goce Delchev", Faculty of Economics, Shtip, Republic of North Macedonia
}

\author{
Scientific paper \\ UDC: $677.3-037: 620$ \\ doi: $10.5937 /$ tekstind2001004M
}

\begin{abstract}
The enzymatic treatment of textiles significantly improves some of their physicochemical properties as well as increases their aesthetic values and comfort of use. Enzymes can be used in order to develop environmentally friendly processes by reducing the concentration of chemical agents, water and energy consumption. Wool fabrics were pretreated with hydrogen peroxide in the presence of stabiliser imino disuccinic acid sodium salt (IDAS). The effect of after-treatment of the pre-oxidised wool fabric with commercially produced lipase enzyme on its dyeability with acid dyes, as well as on some of its physico-mechanical properties, was assessed. Wool fabrics treated with hydrogen peroxide/imino disuccinic acid sodium salt/lipase enzyme exhibit improved wettability and, hence, dyeability with acid dyes, as well as enhanced resistance to felting shrinkage and pilling.
\end{abstract}

Key words: enzyme treatment, wool fabrics, lipase, physical and chemical properties, dyeing, eco-friendly characteristics.

\section{ENZIMSKA OBRADA VUNENIH TKANINA SA LIPAZOM I POBOLJŠANJE NEKIH SVOJSTAVA VUNENIH TKANINA}

\begin{abstract}
Apstrakt: Enzimska obrada tekstila značajno poboljšava neka njihova fizičko-hemijska svojstva i povećava njihove estetske vrednosti i udobnost upotrebe. Enzimi se mogu koristiti za razvoj ekološki prihvatljivih procesa smanjenjem koncentracije hemijskih agenasa, vode i potrošnje energije. Vunene tkanine su prethodno obrađene hidrogen peroksidom u prisustvu stabilizatora (natrijumova so imino disukcinatne kiseline). Procenjen je efekat naknadne obrade preoksidovane vunene tkanine komercijalno proizvedenim enzimom lipaze na njenu obojenost kiselim bojama, kao i na neka njena fizičko-mehanička svojstva. Vunene tkanine tretirane sa hidrogen peroksid/natrijumovom solju imino disukcinatne kiseline/ enzimom lipaze pokazuju poboljšanu vlažnost $i$, samim tim, mogućnost bojenja kiselim bojama, kao i povećanu otpornost na skupljanje i piling.
\end{abstract}

Ključne reči: enzimska obrada, vunene tkanine, lipaza, fizička i hemijska svojstva, bojenje, ekološke karakteristike. 


\section{INTRODUCTION}

Textile industry use various chemicals in different processes and can often have a polluting effect on the environment. The finishing of textile materials generates a large amount of wastewater, which contains organic as well as inorganic residues. Dyehouse effluent that has acidic or alkaline $\mathrm{pH}$ values has also often been observed. The search for new, efficient and eco-friendly alternatives have increased interest in using green catalysts i.e., enzymes. However, with introduction of enzymes in textile industries are ensuring eco-friendly processing of textile products. In general, the use of enzymes leads to a reduction in water and energy consumption. The enzyme treatment not only keeps the fabric looking new after repeated washings, but enhances feel, color, softness and drapeability which translates into a higher quality textile or apparel product $[1,2,3,4]$.

Enzymes are eco-friendly natural macromolecules (biological catalysts) used in the textile industry since 1960 `s. Enzymes have been used for desizing, scouring, polishing, washing, degumming and bleaching of fabrics as well as for decolouring of dyehouse wastewater. A catalyst is any substance which makes a chemical reaction go faster, without itself being changed. All enzymes are made of protein and because they are sensitive to heat, $\mathrm{pH}$ and heavy metal ions. Enzymes are completely biodegradable and accomplish their work quietly and efficiently without leaving and pollutant behind [5].

Lipase enzyme has also found use as a catalyst for production of different products used in cosmetic industry, pulp and paper industry, textile industry, degreasing of leather and also in pharmaceutical industry [6]. Bacterial lipases are glycoproteins, but some extracellular bacterial lipases are lipoproteins. Most of the bacterial lipases reported so far are constitutive and are non-specific in their substrate specificity and a few bacterial lipases are thermostable. Among bacteria, Achromobacter sp., Alcaligenes sp., Arthrobacter $s p$. ., Pseudomonas sp., Staphylococcus, Serratia sp. and Chromobacterium spp. have been exploited for the production of lipases [7].

Environmental protection is becoming a serious concern for textile wet-processors. Many enzyme-assisted textile processes were envisaged as environmentally acceptable alternatives [8]. Lipase enzyme action concentrates on the hydrolysis of fats, especially triglycerides and fatty acids. However, lipase acts on the bonds between protein and lipids on the surface of wool, breaking its hydrophobic barrier [9]. Most of these processes focused on the use of lipases in the modification of wool fibres. The improvement in the dye ability of wool fiber due to enzyme pretreatment may be varied according to the characteristics of wool fiber and dye. Enzyme can digest the amorphous region and induced the dyeing rate positively and decreased the affinity for small molecular weight dye molecule like leveling acid dye. Lipase enzyme treatment is considerably improved the dye ability of wool fiber due to degradation of the hydrophobic F-layer and so the accessibility of the fiber to the aqueous dye liquor increased [10].

Wool is a product of nature, it is formed in the proper skin of a sheep. Wool is a complex natural fibre composed mainly of proteins (97\%) and lipids (1\%), with a heterogeneous morphological structure [11]. It is built from a protein called keratin which is formed in the process of biosynthesis of a-amino acids. Wool fibre is in fact a creation of dead cells. The wool forming cells show diverse structures, shapes and properties. Chemical modification of hydrophobic surface structure of wool fibre leads to the improvement of the functional quality of these fibres. When wool is used as substrate for enzyme catalyzed reactions, a special type of enzyme kinetics is followed. Enzyme diffusion plays a much more decisive role in this heterogeneous system of soluble enzyme and solid substrate. The kinetics does not only depend on the concentration of the reaction partners, the temperature and the $\mathrm{pH}$ value of the liquor, but also on the diffusion of the enzyme to, and into, the solid phase of the substrate and the diffusion of the reaction products out of the solid phase into the liquor. Alkaline peroxide pretreatment improves enzyme diffusion inside wool fibre [12]. Even a mild enzyme treatment of wool can improve the dye ability without causing significant fiber damage [13]. Cegarra et al. (1992) stated that the enzyme treated wool had more amine terminal groups than untreated wool, so enzyme treted wool fiber capable of attracting the dye as well as dyed more intensely dyed than the untreated fibers [14].

Particularly, the application of enzymatic treatments in the finishing of wool fabrics to improve some of their properties is a topic in which research has been intensified in the last years. One of the main aims is the study of finishing processes more environmentally respectful than those traditionally used.

Enzymes are used to improve the softness or to improve the efficiency of the subsequent finishing process either as pretreatment and enzyme-assisted finishing or bio-finishing. For wool top enzyme treatment can be given to impart shrink-resistance finish 
and for woolen fabric, it can be given to improve the dye ability. Nowadays enzymatic treatment of woolen fabric can consider as an alternative shrink proofing process [15]. El Sayed et al. (2002) developed an enzyme-based anti-felting process with the objective of developing an AOX-free process [16]. They also proposed the mechanism for shrink resistance imparted by this enzyme combination. The lipase removed lipids from the outer surface of wool fiber.

The wool industry is facing many challenges, amongst others, competition from other fbres, diminishing consumption, environmental pressures, etc. Innovative methods and processes should continuously be developed to produce products which will improve the competitiveness of the industry. Particularly, the application of enzymatic treatments in the fnishing of wool fabrics to improve some of their properties is a topic in which research was intensifed in the last years. One of the main aims is the study of fnishing processes more environmentally respectful than those traditionally used [17].

The present work aims to utilise stabilised hydrogen peroxide $\left(\mathrm{H}_{2} \mathrm{O}_{2}\right)$ followed by lipase enzyme to improve some properties of wool, such as shrink proofing and enhanced dyeability.

\section{EXPERIMENTAL PART}

\subsection{Materials}

- Fabrics: Wool fabric samples of plain weave $\left(236 \mathrm{~g} / \mathrm{m}^{2}\right)$, produced from wool originating from one variety Macedonian Merino sheep (mean fbre diameter $24 \mu \mathrm{m}$ );

- Enzyme: Lipase F-AP 15 (EC 3.1.1.3) from Sigma-Aldrich, Germany. It is a light brown powder, preparation and produced by submerged fermentation from Rhizopus oryzae, with a declared activity of 30 units/mg. One unit corresponds to the amount of enzyme which releases 1 umol fatty acid from triglycerides per minute at $\mathrm{pH} / 7.2$ and $37^{\circ} \mathrm{C}$ (olive oil as substrate). Process Parameters: Optimum temperature/ $40^{\circ} \mathrm{C} ; \mathrm{pH} / 6.5-7.5$ (optimum 7.2); Time/ 30-60 min; Dosage/ 0.5\%$2.0 \%$ owm (on the weight of the material). Storage temperature $2-8^{\circ} \mathrm{C}$.

- Chemicals: Hydrogen peroxide $(30 \% \mathrm{w} / \mathrm{w})$ was supplied by Clariant, Switzerland. Imino disuccinic acid sodium salt (IDAS), was supplied by Bayer, Germany. Sandozin NRW (non-ionic wetting agent, polyglycol ether) was supplied from Clariant Chemicals, Switzerland.

- $\mathrm{NaOH}, \mathrm{Na}_{2} \mathrm{CO}_{3^{\prime}} \mathrm{Na}_{2} \mathrm{SO}_{3^{\prime}} \mathrm{NaHCO}_{3^{\prime}}$ were obtained from Sigma Aldrich.

- All other chemicals used in this study were of analytical grade.

- Four acid dyes were used in this investigation (Table 1). They were of commercial grade.

\subsection{Treatment methods}

Scouring. Before any fnishing treatment, the wool fabric must be scoured in order to remove the natural and any oily lubricants added before the carding and combing processes that can hinder the successful operation of application of enzyme. Pretreatment of wool fabric with sodium carbonate was carried out in the bath (the material liquor ratio 1:30) containing $1.8 \mathrm{~g} / \mathrm{L}$ sodium carbonate and $1.5 \mathrm{~g} / \mathrm{L}$ Sandozin NRW (nonionic agent) at $60^{\circ} \mathrm{C}$ for $30 \mathrm{~min}$, followed by thorough rinsing with cold water and fnally air-drying at an ambient temperature.

Bleaching. Wool fabric was treated with $40 \mathrm{ml} /$ ILhydrogen peroxide solution $(30 \% \mathrm{w} / \mathrm{w})$ at $65^{\circ} \mathrm{C}$ and $\mathrm{pH} / 8$ (adjusted by sodium carbonate) for $90 \mathrm{~min}$.

Table 1: Acid dyes used in dyeing of wool fabrics

\begin{tabular}{|c|c|c|c|c|}
\hline Dye & Commercial name & Type & Functional class & Supplier \\
\hline 1 & Acid Blue 203 & Acid & Monosulphonic & Egypt Colors, Egypt \\
\hline 2 & Acid Red 1 & Acid & Acid fast (monoazo) & POL, Poland \\
\hline 3 & Telon Red GW & Acid & Acid milling (monoazo) & DyStar, Germany \\
\hline 4 & Polar Red 3BN 140\% & Acid & $\begin{array}{c}\text { Acid supermilling } \\
\text { (monoazo) }\end{array}$ & Ciba-Geigy, Switzerland \\
\hline
\end{tabular}


the liquor ratio was 30:1. The $\mathrm{pH}$ of the reaction was checked every $10 \mathrm{~min}$ and adjusted accordingly to maintain $\mathrm{pH} / 8$. Stabiliser, (imino disuccinic acid sodium salt, IDAS) $(0.05 \mathrm{~mol} / \mathrm{L})$, was added to the bleaching bath. The fabric was then rinsed with water and allowed to dry.

Treatment of wool fabric with lipase. After the pretreatments, wool fabric samples were treated with the enzyme Lipase F-AP 15 in the bath (the material liquor ratio $1: 30$ ) containing varying amounts of lipase $(0.5,1$ and $2 \%$ owm). The treatment was carried out at $50^{\circ} \mathrm{C}$ and $\mathrm{pH} / 7$ for $1 \mathrm{~h}$; the liquor ratio was 30:1. Treated samples were washed at $40^{\circ} \mathrm{C}$ and then treated at $80^{\circ} \mathrm{C}$ for $10 \mathrm{~min}$ to deactivate the enzyme. This was followed by thorough rinsing with distilled water and, finally, air-drying at room temperature.

Dyeing procedures. The dyeing of untreated wool, as well as that treated with hydrogen peroxide/ IDAS or hydrogen peroxide/IDAS/lipase, was carried out using the exhaustion technique.

Dyeing of wool fabric with acid dyes. The dyeing of untreated as well as treated wool fabrics was carried out using $1.5 \%$ owm concentration of acid dyes $1,2,3$ or 4, using a liquor ratio of $30: 1$, in the presence of $10-15 \%$ Glaubers salt, $1.5 \mathrm{~g} / \mathrm{L}$ Sandozin NRW (nonionic agent) with $\mathrm{pH}$ value of the bath 4.5-5.5, at $90{ }^{\circ} \mathrm{C}$ for $100 \mathrm{~min}$. For adjusting the $\mathrm{pH}$ in bath, appropriate amount of sodium carbonate or acetic acid were used. The conditions of dyeing are illustrated in Table 2. Wool fabric was immersed in the dye bath containing the above recipe and was stirred for 15 miutes. The dye bath was heated to $90^{\circ} \mathrm{C}$, was added sodium sulphate (Glaubers salt) and the temperature was maintained for another 100 minutes with stirring. The dyed wool fabric was rinsed thoroughly with running water and air-dried.

\subsection{Analytical methods}

All the samples (control-untreated fabric, pretreated and enzyme-treated) were subjected to various testing for physicochemical properties in order to check the effect of treatment on these properties. Prior to the measurements, samples were conditioned for $24 \mathrm{~h}$ at $20^{\circ} \mathrm{C}$ and $65 \%$ relative humidity. The tests included:

Whiteness index - The degree of whiteness of the wool fabrics was measured with a spectrophotometer (Datacolor) using the CIE method according to EN ISO 105-J02:1997(E) standard. The degree of whiteness of the wool fabrics was given as W-CIE. Each value is an average of three measures determined on different positions on the wool sample.

Weight loss - The weight loss as result of the oxidative and enzymatic treatments was determined by weighing the fabric samples before and after treatment and was expressed in percent. All samples with approximate dimensions of $10 \times 10 \mathrm{~cm}$ were left in oven at $105 \pm 2^{\circ} \mathrm{C}$ for $2 \mathrm{~h}$ then placed in a desiccator for balancing and weighted until constant weight. Assays were performed in duplicate. The weight loss of each sample was calculated as follows, shown in Eqn 1:

$$
\text { Weight loss }(\%)=\frac{w 1-w 2}{w 1} \times 100
$$

where $\mathbf{W}_{1}$ : the dry weight of fabric sample before treatment and $\mathbf{W}_{2}$ : the dry weight of the same fabric sample after treatment.

Alkali solubility - The alkali solubility of the untreated as well as some of the treated fabrics was evaluated using the standard method ASTM D1283-85. One gram of wool sample afer being dried in an oven at $110{ }^{\circ} \mathrm{C}$ for 15 min was weighed and then was put into a beaker containing $100 \mathrm{ml}$ of sodium hydroxide of $0.1 \mathrm{~N}$ at $65^{\circ} \mathrm{C}$ for $1 \mathrm{~h}$. Then the contents were fltered

Table 2: Dyeing conditions of wool fabrics with acid dyes

\begin{tabular}{|c|c|c|c|c|}
\hline Ingredient & Dye 1 & Dye 2 & Dye 3 & Dye 4 \\
\hline Dye conc. (\% owm) & 1.5 & 1.5 & 1.5 & 1.5 \\
\hline Sodium sulphate (\% owm) & 10 & 10 & 15 & 15 \\
\hline $\mathrm{pH}$ (adjusted by acetic acid) & 4.5 & 5 & 5 & 5.5 \\
\hline Leveling agent, Albegal A (\%) & $/$ & $/$ & 0.5 & 0.5 \\
\hline Temperature $\left({ }^{\circ} \mathrm{C}\right)$ & 90 & 90 & 90 & 90 \\
\hline Dyeing time (min) & 100 & 100 & 100 & 100 \\
\hline
\end{tabular}


and rinsed with distilled water for $5 \mathrm{~min}$ and dried in an oven at $110^{\circ} \mathrm{C}$ for $1 \mathrm{~h}$. Afer being desiccated, the alkali solubility of the samples was calculated as a percentage of the original weight according to the following relation, shown in Eqn 2:

$$
\text { Alkali solubility }(\%)=\frac{S 1-S 2}{S 1} \times 100
$$

where $\mathbf{S}_{1}$ : the dry weight of sample before sodium hydroxide treatment and $\boldsymbol{S}_{2}$ : the dry weight of sample afer sodium hydroxide treatment. Values are the average of three replicates.

Water absorbency - The absorbency of the treated as well as the untreated wool fabrics was estimated according to AATCC Test Method 79-2010 standard test conditions. This test method is designed to measure the water absorbency of textiles by measuring the time it takes a drop of water placed on the fabric surface to be completely absorbed into the fabric. A drop of water was allowed to fall from a fixed height onto the taut surface of a test specimen. A measured drop of water is placed on the fabric $1 \mathrm{~cm}$ from the surface. Time is recorded until the water drop absorbs completely. Values are given as the mean of three replicates.

Felting shrinkage - Fabrics of wool and related animal fbres will shrink when subjected to alternating compression and relaxation in aqueous medium. This contraction which is known as milling or felting shrinkage is due to the migration of the fbres, their unique scale structure and elasticity. To do this, the wool fabric samples were frst marked $10 \times 10 \mathrm{~cm}$. Then they were subjected to milling under laboratory conditions in a soap bath of $1 \%$ (the material liquor ratio 1:40) for $45 \mathrm{~min}$ at $50^{\circ} \mathrm{C}$. Te milling solution was prepared as follows: 10-g soap flakes are dissolved in hot water and diluted to $1 \mathrm{~L}$ using a graduated cylinder. Afer this treatment, the samples were removed from the soap solution, rinsed in cold water and dried, and then they were laid flat on the bench and measured, with a steel ruler. If the length is $\mathbf{a}_{\mathbf{1}}(\mathrm{cm})$ and the breadth $\mathbf{b}_{\mathbf{1}}(\mathrm{cm})$, before treatment, Initial area $\left(\mathbf{I}_{1}\right)=\mathbf{a}_{\mathbf{1}}$ $\times b_{1}\left(\mathrm{~cm}^{2}\right)$. If the length is $\mathbf{a}_{2}(\mathrm{~cm})$ and the breadth $\mathbf{b}_{2}$ $(\mathrm{cm})$, afer treatment, fnal area $\left(\mathbf{I}_{2}\right)=\mathbf{a}_{\mathbf{2}} \times \mathbf{b}_{2}\left(\mathrm{~cm}^{2}\right)$ [17]. The felting shrinkage was assessed using the following relation, shown in Eqn 3:

$$
\text { Felting shrinkage }(\%)=\frac{\mathrm{I} 1-\mathrm{I} 2}{\mathrm{I} 1} \times 100
$$

Pilling resistance - Pilling resistance of fabric samples was determined according to BS EN ISO 12945-2:2000 (Modifed Martindale method) using a pilling tester. This method is intended for the determination of the resistance to pilling and surface change of textile fabrics. The standard atmosphere for conditioning and testing textilesas directed in ISO 139 was used, i.e. $65 \pm 2 \%$ relative humidity and $20 \pm$ $2{ }^{\circ} \mathrm{C}$ temperature. The samples are visual assessment on a scale from $A, B$ to $C$ where: sample $\mathbf{A}$ is best (No change, for zero pills); $\mathbf{B}$ - for three to five pills and sample $\mathbf{C}$ for more than five pills.

Tensile strength loss - Tensile strength of a woven fabric is one of the most important mechanical properties. Tensile strength is the ratio between the maximum load that a material can support without fracture and the original cross-sectional area of the material. The tensile strength of the fabric samples was determined according to ASTM D5035-90 (strip test) with an Instron Tensile Tester Model 4411 (Instro Inc., USA) under standard atmospheric condition (65 \pm $2 \%$ relative humidity and $21 \pm 1^{\circ} \mathrm{C}$ temperature). Sample size had a width of $5 \mathrm{~cm}$ and length $18 \mathrm{~cm}$. Each specimen was mounted centrally in the pneumatic flat surface clamps of the tensile testing machine and tested. The tensile strength loss is then calculated as percentage of the original sample tensile strength. Te tensile strength loss values are given as the mean of 10 replicates.

$$
\text { Tensil strength loss }(\%)=\frac{\mathrm{T} 1-\mathrm{T} 2}{\mathrm{~T} 1} \times 100
$$

where $\mathbf{T}_{1}$ : tensile strength of untreated sample and $\mathbf{T}_{2}$ : tensile strength of sample afer treatment.

Colour fastness to laundering - The colour fastness of the dyed wool fabrics to washing was determined according to AATCC test method 61-2007 (Color fastness to laundering: accelerated) using a laboratory laundrometer. Evaluate the colour change of the test specimens as directed in ATTCC Evaluation Procedure using the Gray Scale for Colour Change. Grade 5 - negligible or no change as shown in Gray Scale Step 5; Grade 4.5 - change in colour equivalent to Gray Scale Step 4-5; Grade 4 - change in colour equivalent to Gray Scale Step 4; Grade 3.5 - change in colour equivalent to Gray Scale Step 3-4; Grade 3 - change in colour equivalent to Gray Scale Step 3; Grade 2.5 - change in colour equivalent to Gray Scale Step 2-3; Grade 2 - change in colour equivalent to Gray Scale Step 2; Grade 1.5 - change in colour equivalent to Gray Scale Step 1-2; Grade 1 - change in colour equivalent to Gray Scale Step 1. 


\section{RESULTS AND DISCUSSION}

\subsection{Effect of treatment of wool fabric with the hydrogen peroxide/IDAS/lipase system}

Wool fabrics were treated with hydrogen peroxide in the presence of stabiliser IDAS. Pretreatment of wool fabric with hydrogen peroxide is essential for improving its degree of whiteness and for preparing the fabric for subsequent enzymatic treatment. The improvement in the degree of whiteness of the oxidised wool fabrics, compared with the untreated fabric, was used as a measure of the efficiency of the bleaching bath in the oxidation of the wool surface. The whiteness index of the treated fabrics was then assessed. The degree of whiteness of the wool fabrics treated with hydrogen peroxide in the presence of IDAS was 44.3 compared with 42.3 and 30.1 for those samples treated with hydrogen peroxide alone and untreated, respectively. Wool fabrics, pre-oxidised by hydrogen peroxide in the presence of IDAS, were after-treated with lipase enzyme at different concentrations $(0.5 \%$, $1 \%$ and $2 \%$ owm) at optimum $\mathrm{pH}$ and temperature $\left(\mathrm{pH} 7\right.$ and $\left.50^{\circ} \mathrm{C}\right)$ for $1 \mathrm{~h}$. The effect of these treatments on the degree of whiteness, felting shrinkage and weight loss were assessed. Results in Table 3 show that the treatment of wool fabric with the hydrogen peroixde/IDAS/lipase system increased its degree of whiteness compared with the untreated sample. The treatment of wool with the hydrogen peroxide/IDAS/ lipase enzyme increases its resistance to felting shrinkage as the enzyme concentration increases up to $1 \%$ owm. A further increase in the enzyme concentration has no effect on the felting resistance of wool fabrics.

The effect of treatment of wool with hydrogen peroxide/IDAS/lipase ( $1 \%$ owm) on some physicochemical properties was assessed and is summarised in Table 4.

The data in Table 4 show that the alkali solubility of the enzyme-treated wool fabrics increased to $13.2 \%$, compared with $10.8 \%$ for the untreated sample, and reached $17.9 \%$ in the case of enzyme-treated fabrics. Values are within the acceptable limit. Also data from table show that the water absorbency of the wool fabrics is highly enhanced by treatment with the hydrogen peroxide/IDAS/lipase system (23 s) compared with $2300 \mathrm{~s}$ and $1420 \mathrm{~s}$ in the cases of the untreated and the hydrogen peroxide-treated wool fabric, respectively. Treatment of the wool fabric with the hydrogen peroxide/IDAS/lipase enzyme system lowered its tendency to form pills. Treatment of wool

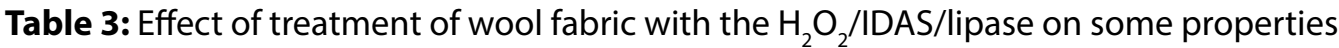

\begin{tabular}{|l|c|c|c|}
\hline Treatment & Whiteness index & Felting shrinkage, \% & Weight loss, \% \\
\hline Untreated fabric & 30.1 & 15.1 & 8.3 \\
\hline $\mathrm{H}_{2} \mathrm{O}_{2}$ alone & 42.3 & 10.6 & 0.4 \\
\hline $\mathrm{H}_{2} \mathrm{O}_{2}$ /IDAS & 44.3 & 6.7 & 1.2 \\
\hline $\mathrm{H}_{2} \mathrm{O}_{2}$ /IDAS/lipase 0.5\% & 40.2 & 5.2 & 3.2 \\
\hline $\mathrm{H}_{2} \mathrm{O}_{2}$ /IDAS/lipase 1\% & 45.6 & 4.2 & 4.1 \\
\hline $\mathrm{H}_{2} \mathrm{O}_{2}$ /IDAS/lipase 2\% & 43.1 & 4.1 & 4.6 \\
\hline
\end{tabular}

Table 4: Effect of treatment of wool fabric with the $\mathrm{H}_{2} \mathrm{O}_{2} /$ IDAS/lipase on some physicochemical properties

\begin{tabular}{|l|c|c|c|c|}
\hline Treatment & $\begin{array}{c}\text { Alkali solubility, } \\
\%\end{array}$ & $\begin{array}{c}\text { Water } \\
\text { absorbency, s }\end{array}$ & Pilling & $\begin{array}{c}\text { Decrease } \\
\text { in tensile } \\
\text { strength, \% }\end{array}$ \\
\hline Untreated fabric & 10.8 & 2300 & $\mathrm{C}$ & $/$ \\
\hline $\mathrm{H}_{2} \mathrm{O}_{2}$ alone & 15.3 & 1420 & $\mathrm{~B}$ & 5.2 \\
\hline Lipase 1\% & 13.2 & 990 & $\mathrm{C}$ & 4.6 \\
\hline $\mathrm{H}_{2} \mathrm{O}_{2} /$ IDAS/lipase 1\% & 17.9 & 23 & $\mathrm{~A}$ & 6.9 \\
\hline
\end{tabular}


with the hydrogen peroxide/IDAS/lipase system resulted in a remarkable decrease in the tensile strength of the fabric.

\subsection{Effect of treatment of wool fabric with the hydrogen peroxide/IDAS/lipase system on wool dyeing with acid dyes}

The wool fabrics were dyed with four different acid dyes. Untreated and treated wool fabrics were dyed in the same bath for $45 \mathrm{~min}$. The dyed samples were removed from the dyeing bath and washed with cold water, squeezed and dried. The colour fastness to laundering of the dyed untreated wool fabrics as well as the treated wool fabrics were assessed and are shown in Table 5. The data in this table illustrate that wool fabrics treated with the hydrogen peroxide/IDAS/lipase system and dyed with acid dyes have slightly better colourfastness to laundering.

Table 5: Colour fastness to laundering of wool fabric treated with the $\mathrm{H}_{2} \mathrm{O}_{2}$ /IDAS/lipase and dyed with acid dyes

\begin{tabular}{|c|c|c|}
\hline Dye & Treatment & $\begin{array}{l}\text { Colourfastness } \\
\text { to laundering }\end{array}$ \\
\hline \multirow[t]{4}{*}{1} & Untreated & 4 \\
\hline & $\mathrm{H}_{2} \mathrm{O}_{2} /$ IDAS & $4-5$ \\
\hline & Lipase 1\% & $4-5$ \\
\hline & $\mathrm{H}_{2} \mathrm{O}_{2} /$ IDAS/lipase $1 \%$ & 5 \\
\hline \multirow[t]{4}{*}{2} & Untreated & $4-5$ \\
\hline & $\mathrm{H}_{2} \mathrm{O}_{2} /$ IDAS & $4-5$ \\
\hline & Lipase 1\% & $4-5$ \\
\hline & $\mathrm{H}_{2} \mathrm{O}_{2} /$ IDAS/lipase $1 \%$ & 5 \\
\hline \multirow[t]{4}{*}{3} & Untreated & 4 \\
\hline & $\mathrm{H}_{2} \mathrm{O}_{2} /$ IDAS & $4-5$ \\
\hline & Lipase 1\% & $4-5$ \\
\hline & $\mathrm{H}_{2} \mathrm{O}_{2} /$ IDAS/lipase $1 \%$ & $4-5$ \\
\hline \multirow[t]{4}{*}{4} & Untreated & $4-5$ \\
\hline & $\mathrm{H}_{2} \mathrm{O}_{2} /$ IDAS & $4-5$ \\
\hline & Lipase $1 \%$ & $4-5$ \\
\hline & $\mathrm{H}_{2} \mathrm{O}_{2} /$ IDAS/lipase $1 \%$ & 5 \\
\hline
\end{tabular}

\section{CONCLUSIONS}

In general, it is concluded that enzymatic treatment of wool fabrics had a positive influence on some physical and chemical properties of the fabrics. The enzymatic treatment with the studied lipase produces an improvement in water absorbency, pilling resistance and felting shrinkage and a slight increase in weight loss, tensile strength loss and alkali solubility of the fabric. The data in this table illustrate that wool fabrics treated with the hydrogen peroxide/IDAS/ lipase system and dyed with acid dyes have slightly better colourfastness to laundering.

\section{REFERENCES}

[1] Mojsov, K. (2014). Biopolishing enzymes and their applications in textiles: A review. Tekstilna industrija, 61 (2), 20-24.

[2] Shukla, S. R. (2001). Environment friendly processing of protein fibers. Indian Journal of Fibre and Textile Research, 26 (2), 116-124.

[3] Hemmpel, W. H. (1991). The Surface Modification of Woven and Knitted Cellulosic Fibre Fabrics by Enzymatic Degradation. International Textile Bulletin Dyeing /Printing/Finishing, 37(3), 5-14.

[4] Mojsov, K., Janevski, A., Andronikov, D., Gaber, S. (2017). Determination of weight loss of cotton fabrics in enzymatic treatment. Tekstilna industrija, 64 (1), 44-48.

[5] Pardeshi, P. D., Paul, R., Manjrekar, S. G. (2002). Wool Processing, Challenges and prospects. Asian Textile Journal, 11 (4), 52-57.

[6] Eugene, W. S. (1974). Industrial application of microbial lipases: A review. J Am Oil Chem Soc, 51, 1216.

[7] Kamini, N. R., Mala, J. G. S. (1998). Puvanakrishnan, R., Lipase production from Aspergillus niger by solid-state fermentation using gingelly oil cake. Process Biochem; 33, 505-511.

[8] Sekar, N. (1999). Application of natural colourants to textiles-Principles and limitations. Colourage, 46 (7), 33-34.

[9] Fornelli, S. (1993). Enzymatic Treatment of Protein Fibres-State-of-the-art Biotechnology. Dyer, 178, 29-33.

[10] Kantouch, A., Raslan, W. M., El-Sayed, H. (2005). Effect of lipase pretreatment on the dye ability of wool fabric. Journal of Natural Fibers, 2, 35-48. 
[11] Heine, E., Höcker, H. (1995). Enzyme treatments for wool and cotton. Rev. Prog. Coloration, 25, 57-63.

[12] Silva, C. J. S. M., Prabaharan, M., Gübitz, G., Cavaco-Paulo, A. (2005). Treatment of wool fibres with subtilisin and subtilisin-PEG. Enzyme and Microbial Technology, 36, 917-922.

[13] Riva, A., Cegarra, J., Prieto, R. (1993). The role of an enzyme in reducing wool shrinkage. Journal of Society for Dyers and Colourists, 109 (5/6), 210-213

[14] Cegarra, J., Riva, A., Gacen, J., Naik, A. (1992). Influence of enzymatic treatments on wool dyeing. Tinctoria, 89(4), 64-67.
[15] Leven, R., Cohen, Y., Barkai, D. (1996). Applying protease to confer improved shrink resistance to wool. Journal for Society for Dyers and Colorists, 112 (1), 6-10.

[16] El Sayed, H., Hamed, R. R., Kantouch, A., Heine, E., Hocker, H. (2002). Enzyme wool enzyme-based felt proofing of wool. AATCC Review, 2 (1), 25-28.

[17] Mojsov, K. (2017). Enzymatic treatment of wool fabrics - opportunity of the improvement on some physical and chemical properties of the fabrics, The Journal of The Textile Institute, 108 (7), 1136-1143.

Rad primljen: 18.11.2019.

Rad prihvaćen: 20.01.2020. 